\title{
Philip Cooke and Luciana Lazzeretti (eds): Creative Cities, Cultural Clusters and Local Economic Development
}

\author{
Edward Elgar, Cheltenham, 2007, ISBN 10: 1847202683
}

\author{
Frank G. van Oort
}

Received: 17 July 2008/Accepted: 17 July 2008/Published online: 2 August 2008

(C) The Author(s) 2008

Starting from the early 1990s, spatial economic sciences shifted focus towards the role of culture in urban and regional development. Embedded in societal changes (like increasing welfare levels, the increasing opportunities for interaction due to information and communication technologies, and the increasing networking of people, information, goods and services), this 'cultural turn' questions previously robust interpretations and commonalities concerning agglomeration and urban development. It suggests that firms and employees are becoming more footloose (Thrift 2000). Still, a remarkable number of societal and economic activities continue to cluster in cities. However, it no longer seems to be predefined who and what exactly the relevant actors and institutions are, whether workers are still the same as employees, whether entrepreneurs are hardworking independent labourers making a small-scale living, whether profits determine chances of survival in markets and whether economic development is completely determined by investments in labour, capital and technology. The new glue in postmodern geography is apparently culture: creative knowledge workers choose culture- and amenity-rich environments to reside and work, to network globally and act locally, leading regional and urban economies to grow and become competitive (Catsells 2000; Florida 2002). Important concepts related to this discussion are: social aspects of economics; the institutional complexity of markets; image as a factor determining location; the shift from production to consumption in organizational theory; intelligent technologies; cooperation in research and development; informal circuits; time-space dependency; and evolutionary and institutional spatial-economic frameworks (Thrift and Olds 1996). Just putting these concepts together (which was done in the early 1990s) reads like a manifesto that, although firmly embedded in the geographic epistemic community, encounters thorough criticisms (RodriguezPose 2001; Barnett 1998). How new is the concept of culture in explaining urban

F. G. van Oort ( $\square)$

Department of Economic Geography, Utrecht University, Utrecht, The Netherlands

e-mail: f.vanoort@geo.uu.nl 
development? How can culture as a determining factor for localized economic growth be measured and assessed, and distinguished from other factors? How opposing or complementary are the paradigms of economic realists and cultural constructionists? Can culture as a construct for local economic (re)generation be actively pursued and marketed by policy-makers, as is currently actually the case? What empirical proof is there to answer these questions?

The answer to the last question is actually: too little. The book, edited by Cooke and Lazzeretti, therefore tries to contribute to exactly these questions. It positions itself at the core of the recent debate on modern economies and the relationship between culture, creativity and models of local development. The book collects 14 papers that all individually seem to stress that culture is a possible flywheel of economic development for cities and places rich in cultural resources and networked connections. The proof of the eating is in empirical testing though, in such a manner that conclusions on the cultural turn can be generalized. Most papers in the book do so by focussing on case studies of creative and cultural industries in certain regions, mostly in Europe. Some chapters focus on more generic frameworks of analysis, specifically on conceptualization (Cooke), fixed book pricing (Palma Martos), localization and urbanization patterns (Lorenzen \& Frederiksen) and urban networks and agglomeration externalities (Trullen \& Boix). This guarantees that there is a mixture of qualitative and quantitative research in the volume.

While reading the book, however, three pressing observations emerged:

First, and quite basically, the definitions of creative cities, cultural clusters and local economic development (the title of the book) are as heterogeneous in the contributions as they are in the literature in general. This lack of consistency is (still) a drawback of the literature and one that is not solved in this issue. In the introductory chapter, Cooke and Lazzeretti rightly start off with the distinction between the cultural economy in general and creative industries specifically. The former (museums, concert halls and theatres) tend to be characterized by market failure and are therefore usually subsidized or sponsored by industry or government (as a public good). Creative industries (like new media or creative consultants) make money and should be conceptualized as business-economic entities. This distinction is useful, but not thoroughly applied throughout the book, and also not evaluated. What is more striking about the definition is that the concept of the socalled creative class in relation to urban economic development is ignored in the introductory chapter (the concept is analysed explicitly in the chapter by Capone). The popular and appealing concept of the creative class suggests that creativity potentially hides in many kinds of occupations, since people do not have to be highly educated to be creative and initiate economic renewal. Florida (2002) argues that the creative class is predominantly attracted by cultural amenities in cities, and directly and indirectly (by spending more than average amounts of time and money outside the household) foster local economic development. Hence, virtually every city wants to become a creative city. Of course there are critiques of Florida's conceptualization (of the definition of creative occupations, the difference between places people work and live, reversed causality of creative people being attracted to fast-growing cities and a minimum local threshold to be able to develop a circular 
causation of growth); however, leaving this local policy-intensive issue out of the scope of the book seems to compromise its multidisciplinary character.

Second, although Cooke and Lazzeretti try to embed the book in potentially guiding, recent theories of creative cities and cultural clusters, their introductory chapter presents three somewhat awkward frameworks. The 'world of production' theory, developed by Michael Storper in the 1990s, focusses on untraded interdependencies as a means of explaining the clustering and networking of industrial firms. There is no explicit role for creativity or cities in this conceptualization. The agro-food sector and rural tourism are dealt with as examples instead. The 'related variety' approach, mainly developed at Utrecht University, is taken as a second benchmarking theory, stating that initial variety, selection and path-dependency as evolutionary concepts are attached to knowledge spillovers and localization economies of firms. Again, the city and creativity do not play a dominant role in this conceptualization. Culinary tourism in rural regions is taken as a fairly unconvincing example of this approach. Finally, the 'regional innovation system' approach stresses the interplay between firms, universities and government institutions in regional platforms of knowledge exchange and innovation. Here, the relationship with local economic growth is not clear-cut, although potential policy interventions aiming for innovation and cooperation are more rightly embedded. Somewhat worrisome is that no linkages between the three approaches are drawn in relation to creative cities and cultural clusters. A missed opportunity? The three approaches also do not function as a guiding base for the 14 chapters to follow, and to which practically none of them refer.

The third difficulty that comes to the fore while reading this book is the question of the general applicability of the research results presented. What insights do the case studies on Singapore, Vancouver, Barcelona, Hollywood, Verona and the Swiss/French Jura provide, which are not currently provided by existing approaches? What policy lessons can we draw from them? The paucity of empirical evidence to support the original arguments of the 'cultural turn' in geographystriking from the outset, as suggested above-is not thoroughly dealt with in this book. Much evidence is suggestive, not being able to pick out culture convincingly as a distinct, significant or stylized concept in empirical analysis. The empirically and statistically excellent chapter by Trullen and Boix on Catalonian urban networks illustrates the gap between its somewhat abstract conclusion on the role of agglomeration externalities on urban growth, and the policy-induced issues on creative cities dealt with in most of the other case studies. Concepts of creativity and culture in geography, however appealing, are not a theory yet and are not unambiguously testable (McCann 2007; Markusen 2003). There remains a mismatch between 'stylized constructs' or somewhat loose conceptualizations, and their inability to support empirical evaluation through hypothesis formulation and testing, required for assessing the usefulness and use of concepts in public policy.

Open Access This article is distributed under the terms of the Creative Commons Attribution Noncommercial License which permits any noncommercial use, distribution, and reproduction in any medium, provided the original author(s) and source are credited. 


\section{References}

Barnett, C. (1998). The cultural turn: Fashion or progress in human geography? Antipode, 30, 379-394. doi:10.1111/1467-8330.00085.

Catsells, M. (2000). The rise of the network society. Oxford: Blackwell.

Florida, R. (2002). The rise of the creative class. New York: Basic Books.

Markusen, A. (2003). Fuzzy concepts, scanty evidence, policy distance: The case for rigor and policy relevance in critical regional studies. Regional Studies, 37, 699-715. doi:10.1080/003434003 2000108787.

McCann, P. (2007). Observational equivalence? Regional studies and regional science. Regional Studies, 41, 1209-1221. doi:10.1080/00343400701624494.

Rodriquez-Pose, A. (2001). Killing economic geography with a 'cultural turn' overdose. Antipode, 33, 176-182. doi:10.1111/1467-8330.00176.

Thrift, N. (2000). Pandorra's box? Cultural geographies of economies. In G. L. Clark, M. P. Feldman, \& M. S. Gertler (Eds.), The Oxford handbook of economic geography (pp. 698-704). Oxford: Oxford University Press.

Thrift, N., \& Olds, K. (1996). Refiguring the economic in economic geography. Progress in Human Geography, 20, 311-337. doi:10.1177/030913259602000302. 